Y. Grynchuk,

Doctor of Economic Sciences, Professor,

Head of Management department of Bila Tserkva National Agrarian University

ORCID ID: 0000-0003-0297-7432

N. Koval,

PhD in Economics, Associate Professor, Associate Professor

of Management department of Bila Tserkva National Agrarian University

ORCID ID: 0000-0003-1244-9297

DOI: $10.32702 / 2306-6792.2020 .11 .37$

\title{
IMPROVING THE MANAGEMENT OF THE MILK MARKET DEVELOPMENT TO ENSURE FOOD SECURITY OF UKRAINE
}

Ю. С. Гринчук,

А. е. н., професор, завідувач кафедри менеджменту, Білоцерківський національний аграрний університет

Н. В. Коваль,

к. е. н., доцент, доцент кафедри менеджменту, Білоцерківський національний аграрний університет

\section{УАОСКОНААЕННЯ УПРАВАІННЯ РОЗВИТКОМ РИНКУ МОАОКА 3 МЕТОЮ}

ЗАБЕЗПЕЧЕННЯ ПРОАОВОАЬЧОЇ БЕЗПЕКИ УКРАЇНИ

The current state, main tendencies and problems of development of the Ukrainian milk market are investigated. It is proved that there is an internal shortage of dairy raw materials in Ukraine: to provide enough milk and milk products for the population of Ukraine in 2019, according to The Adult Health Nutrition Guidelines, approved by the Minister of Health of Ukraine, at least 11500 tonnes of milk should have been produced, while in fact only $\mathbf{9 6 8 6 , 9}$ tonnes were produced by all kinds of farms together. The reasons for the decrease in milk production have been identified: cow population decreasing in 2019 by 620 thousand animals, or $25,38 \%$, versus 2013 , and stabilizing of the average yearly milk yields in households.

Factors affecting the decrease in the number of cows are analyzed. Among agricultural enterprises the key factors are the rapid implementation of the land market in Ukraine, incomplete payouts of compensation provided by state support programs in 2019, as well as rumors about the significant reduction of these programs in 2020. Factors that influence the decrease in cow population at household farms include declining labour resources in rural areas due to migration and aging of the rural population that drives the elderly people who are mostly involved in milk production, to resign from owning cattle, not having sufficient means of sustaining it. Low purchasing prices for milk are also among the factors.

Budget support programs for dairy cattle breeding in 2018-2019 are considered. Proposals to improve the management of the development of the milk market, in particular, the need to develop a long-term program of development of the dairy industry of Ukraine are substantiated. This program needs to span at least five years, which is driven by the long term of return on investment in milk cattle farming. It should provide for preferential conditions and priority right to purchase land allotments by dairy farming enterprises; maintaining a number of current budget support programs for livestock (such as offsetting the cost of bank-financed assets; partial reimbursement of the cost of livestock facilities; partial reimbursement of costs for stockbreeding animals, semen and embryos, subsidies for growing stock); replacement of special budgetary subsidies for keeping cows with subsidies for the volume of products sold.

Аосліджено сучасний стан, основні тенденції та проблеми розвитку ринку молока України. Аоведено, що в Україні спостерігається внутрішній дефіцит молочної сировини: для забезпечення населення України молоком та молочними проАуктами у 2019 р., згідно 3 "Рекомендаціями щодо зАорового харчування дорослих", затверАжених міністром охорони здоров'я України, потрібно було виробити мінімум 11500 тис. т молока, тоді як всіма категоріями господарств було вироблено лише 9686,9 тис. т молока. Встановлено причини зменшення обсягів виробництва молока: скорочення поголів'я корів у 2019 р. порівняно з 2013 р. на 620 тис. голів або на $25,38 \%$ та стабілізація середніх річних надоїв молока у домогосподарствах. Проаналізовано чинники, що впливають на зменшення поголів'я корів. У сільськогосподарських підприємствах головною причиною $є$ швидка імплементація ринку землі в Україні, неповні виплати компенсацій за існуючими програмами держпідтримки у 2019 р. та чутки про їх суттєве скорочення у 2020 р. Ао чинників, які впливають на скорочення поголів'я корів у домогосподарствах, належать зменшення кількості трудових ресурсів у сільській місцевості внаслідок процесів міграції, "старіння - сільського населення, внаслідок чого люди літнього віку, які переважно займаються виробництвом молока, позбавляються від худоби, не маючи сил ії утримувати, а також низькі закупівельні ціни на молоко.

Розглянуто програми бюАжетної підтримки молочного скотарства у 2018-2019 роках. Обгрунтовано пропозиції щодо Удосконалення управління розвитком ринку молока, зокрема, необхідність розробки довгострокової програми розвитку молочної галузі України, яка повинна бути розрахована не менш, ніж на п'ять років, що пов'язано з тривалим терміном окупності об'єктів молочного скотарства. В ній необхідно передбачити пільгові умови та пріоритетне право на купівлю земельних наділів сільськогосподарськими підприємствами, що займаються молочним скотарством; збереження ряду чин- 
них програм бюджетної підтримки галузі тваринництва (компенсація вартості об'єктів, профінансованих за рахунок банківських кредитів; часткове відшкодування вартості тваринницьких об'єктів; часткове відшкодування вартості племінних тварин, сперми та ембріонів; дотація за молодняк); заміну спеціальних бюджетних дотацій за утримання корів дотаціями на обсяг реалізованої продукції.

Key words: deficit, milk market, state support of the producers.

Ключові слова: ринок молока, дефічит, державна підтримка виробників.

\section{INTRODUCTION}

The milk market is an integral part of the food market and plays an important role in shaping the state's food security. Currently, there are quite contradictory statements in the media space of Ukraine regarding the problems and prospects of the development of the milk market in the country. Thus, according to the data of the International Farm Comparison Network (IFCN), Volodymyr Andriets, an analyst of the Ukrainian Milk Producers Association notes that Ukraine is ranked 22nd in the ranking of world milk producers and has every chance to increase its share in the structure of world exports. Among the main competitive advantages of Ukraine, the expert lists the price of milk, which is $10 \%$ below the world average, and the increase in the production of extra grade milk (26\% of the total milk production). The role of Ukraine as a world exporter of casein - third largest in the world, butter - fifth largest, skimmed milk powder - eighth largest, and second largest (after New Zealand) exporter of butter to EU countries is also emphasized [1].

Leading researcher of the Department of Economics of Agrarian Production and International Integration of the National Science Center of the Institute of Agrarian Economics (IAE NSC) Olga Kozak, based on the results of the study "Forecast of milk production in Ukraine by 2030: methodology and calculations - [2], emphasizes that, given the current trends in the dairy industry, milk production in Ukraine will decrease by $12.3 \%$ (up to 8830,0 thousand tons) by 2030 compared to 2018 , and there is already a shortage of dairy in the country raw materials, as evidenced by: rising purchase prices corresponding to, and in some places higher than the world, the expansion of up to $600 \mathrm{~km}$ of scales of raw materials of processors, reduction of export and increase of import of dairy products.

Vice President of the Milk Producers Association Anna Lavrenyuk warns that if cow population continues to decline at the same rate as in the second half of 2019, "we are at risk of being left without Ukrainian milk and lose the main budget-forming industry- [3].

\section{THE PURPOSE OF THE STUDY}

The purpose of the study is to analyze the milk market of Ukraine, its current state, and sub- stantiate concrete proposals for improving the management of its formation and development in order to improve its efficiency and ensure food security of Ukraine.

\section{DATA AND METHODS}

The basis of the study is a systematic approach to the study of the formation and development of the milk market in Ukraine. The statistical and economic method, including its methods dynamic, index, structural and graphical analysis, was used in the research process. The data of the State Statistics Service of Ukraine, the Association of Milk Producers, the legislative and regulatory acts of Ukraine, the work of domestic experts on the problem of research, as well as information resources of the Internet are analyzed.

\section{RESULT AND DISCUSSION}

The Adult Health Nutrition Guidelines, approved by the Minister of Health of Ukraine, stated that daily consumption of dairy and sour milk products should be $2.5-3$ servings per day (one serving is a glass of liquid product or $40 \mathrm{~g}$ of solid cheese or $120 \mathrm{~g}$ of homemade cheese) [4]. Similar recommendations are also provided by the USDA Center for Nutrition Policy \& Promotion. Therefore, in order to provide milk and dairy products to the Ukrainian population in 2019, a minimum of 11500 thousand tons of milk was needed (taking into account that the average size of the existing population excluding the temporarily occupied territory of the Autonomous Republic of Crimea and Sevastopol in JanuaryNovember 2019, according to the State Statistics Service of Ukraine, amounted to 42037936 people. Since in 2019 all categories of farms in Ukraine produced 9686.9 thousand tonnes of milk (Fig. 1), we can say that in Ukraine there is indeed an internal shortage of dairy raw materials.

Figure 1 shows that milk production in Ukraine by all categories of farms decreased in 2019 compared to 2010 by 1208.7 thousand tonnes or $11.09 \%$. And if we compare with 2013 (the maximum volume of milk production in the last decade) - by 1503.7 thousand tons or by $13.44 \%$. In 2019 only 9686.9 thousand tonnes of milk was produced in Ukraine, while in $1990-24508.3$ thousand tonnes, in $2000-$ 12657.9 thousand tonnes. 


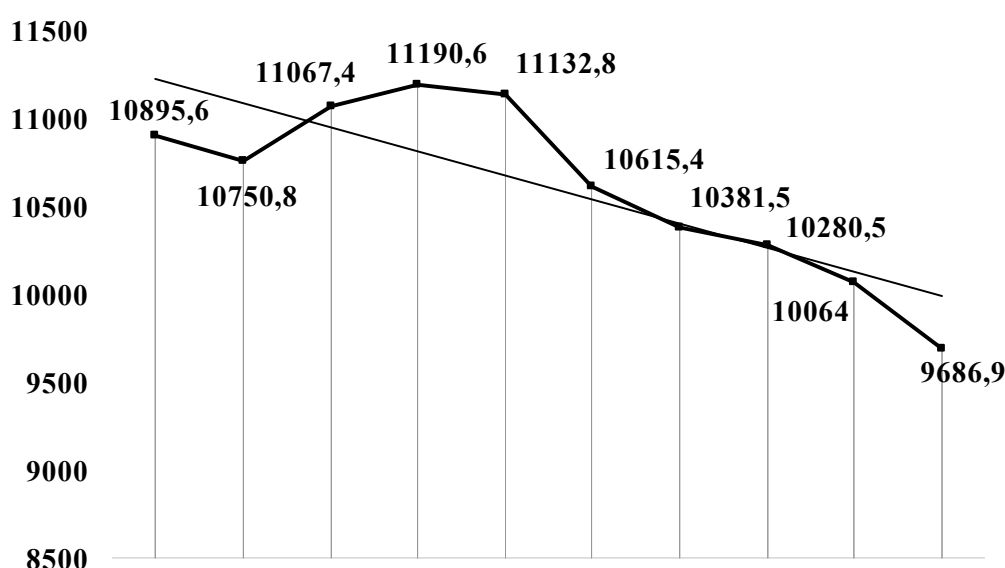

$\begin{array}{llllllllll}2010 & 2011 & 2012 & 2013 & 2014 & 2015 & 2016 & 2017 & 2018 & 2019\end{array}$

Figure 1. Dynamics of milk production by all categories of farms in Ukraine in 2010-2019, thousand tons

Source: built on data to the State Statistics Service of Ukraine.

It should be noted that during 2014-2019, with the annual decrease in the gross milk production in Ukraine, agricultural enterprises in general increased production by $6.21 \%$, while households - decreased by $19.26 \%$ (Table 1). This led to a decrease of 5.19 in the share of households in gross milk production. $n$., which is a positive trend. It is this that gives rise to restrained optimism about the possibility of further increasing the volume of milk production by agricultural enterprises, subject to a prudent state policy to support agricultural producers. However, it is worrying that, by 2017, agricultural businesses have been steadily increasing their milk production, in 2018-2019, we are seeing the opposite trend.

Milk production depends on the number of cows and their productivity. The decrease in milk production is primarily due to the decline in the number of cows that characterize the data in Table 2.

A significant decrease in the number of livestock is observed in all categories of farms. So, in 2019 compared to 2013, the total number of cows decreased by 620 thousand heads or by $25.38 \%$. The number of cows in agricultural enterprises decreased by 122.4 thousand heads or $21.85 \%$, in households - by 497.6 thousand heads or by $26.43 \%$. The share of households in the total cow population fluctuates around $76 \%$.

The calculation of the chain index showed a sharp decline in livestock in agricultural enterprises in 2019 (6.39\%) after stabilization and even a slight increase in 2018. According to experts, the main reason for the decrease in livestock is the rapid implementation of the land market in Ukraine: enterprises with inefficient animal husbandry do not plan to buy land for the organization of animal feeding, so they get rid of animals by concentrating on crop production; efficient enterprises have partially reduced domestic investment in order to accumulate funds for the purchase of the same land [3]. Also notable are the incomplete payment of compensation for existing state support programs in 2019 and rumors of a significant reduction in 2020.

As for the factors affecting the decline in cow livestock in households, one of them is the reduction of labor resources in rural areas, which is related to migration processes. Milk production is mainly done by elderly people who grow old and

Table 1. Milk production by category of farms (thousand tons)

\begin{tabular}{|l|l|l|l|l|l|l|l|l|}
\hline \multirow{2}{*}{ Categories of farms } & \multicolumn{9}{|c|}{ Years } & $\begin{array}{c}2019 \\
\text { in \% till } \\
2013\end{array}$ \\
\cline { 2 - 9 } & 2013 & 2014 & 2015 & 2016 & 2017 & 2018 & 2019 & 86,56 \\
\hline Farms of all categories & 11190,6 & 11132,8 & 10615,4 & 10381,5 & 10280,5 & 10064,0 & 9686,9 & 19,9 \\
\hline Agricultural enterprise & 2558,9 & 2647,5 & 2669,2 & 2705,6 & 2765,7 & 2755,5 & 2717,7 & 106,21 \\
\hline Households & 8631,7 & 8485,3 & 7946,2 & 7675,9 & 7514,8 & 7308,5 & 6969,2 & 80,74 \\
\hline Share of households, \% & 77,13 & 76,22 & 74,86 & 73,94 & 73,1 & 72,62 & 71,94 & - \\
\hline
\end{tabular}

Source: calculated according to the State Statistics Service of Ukraine.

Table 2. Cows by category of holdings, thousand heads

\begin{tabular}{|l|l|l|l|l|l|l|l|l|}
\hline \multirow{2}{*}{ Categories of farms } & \multicolumn{7}{|c|}{ Years } & $\begin{array}{c}2019 \\
\text { in \% till } \\
2013\end{array}$ \\
\cline { 2 - 9 } & \multicolumn{1}{|c|}{2013} & 2014 & 2015 & 2016 & 2017 & 2018 & 2019 & 74,62 \\
\hline Farms of all categories & 2443,0 & 2262,7 & 2166,6 & 2108,9 & 2017,8 & 1919,4 & 1823,0 & - \\
\hline in\% to the previous year & - & 92,62 & 95,75 & 97,34 & 95,68 & 95,12 & 94,98 & - \\
\hline Agricultural enterprise & 560,3 & 529,2 & 505,1 & 484,6 & 466,6 & 467,8 & 437,9 & 78,15 \\
\hline in\% to the previous year & - & 94,45 & 95,46 & 95,94 & 96,29 & 100,26 & 93,61 & - \\
\hline Households & 1882,7 & 1733,5 & 1661,5 & 1624,3 & 1551,2 & 1451,6 & 1385,1 & 73,57 \\
\hline In \% to the previous year & - & 92,08 & 95,85 & 97,76 & 95,50 & 93,58 & 95,42 & - \\
\hline Share of households, $\%$ & 77,07 & 76,61 & 76,68 & 77,02 & 76,88 & 75,63 & 75,98 & - \\
\hline
\end{tabular}

Source: calculated according to the State Statistics Service of Ukraine. 
get rid of livestock without the

Table 3. Average annual milk yield per cow, kg

means to keep it. Also, under the obligations under the Association Agreement with the EU, Ukraine must harmonize its legislation with the provisions of Regulation (EC) No $853 / 2004$ on special rules on food hygiene, including raw milk. In this regard, the new

\begin{tabular}{|c|c|c|c|c|c|c|c|}
\hline \multirow{2}{*}{ Categories of farms } & \multicolumn{6}{|c|}{ Years } & \multirow{2}{*}{$\begin{array}{c}2018 \\
\text { in } \% \text { till } \\
2013\end{array}$} \\
\hline & 2013 & 2014 & 2015 & 2016 & 2017 & 2018 & \\
\hline Farms of all categories & 4455 & 4508 & 4644 & 4735 & 4820 & 4922 & 110,48 \\
\hline in $\%$ to the previous year & - & 101,19 & 103,02 & 101,96 & 101,80 & 102,12 & - \\
\hline Agricultural enterprise & 4833 & 5027 & 5352 & 5643 & 6025 & 6190 & 128,08 \\
\hline in $\%$ to the previous year & - & 104,01 & 106,47 & 105,44 & 106,77 & 102,74 & - \\
\hline Households & 4351 & 4363 & 4437 & 4473 & 4480 & 4559 & 104,78 \\
\hline in $\%$ to the previous year & - & 100,28 & 101,70 & 100,81 & 100,16 & 101,76 & \\
\hline
\end{tabular}

Source: calculated according to the State Statistics Service of Ukraine.

DSTU 3662 milk quality standard came into force on 01.01.2019: "Cow's milk raw. Specifications[5]. The requirements for the quality of extra, higher and first grade milk have increased in accordance with the stated standard. The requirements for second-grade milk have not changed, but its producers (mainly households) may have it delivered to processing plants by 01.01.2020. From that date, a two-year transition period began during which second-grade milk will be accepted for technical purposes only (production of animal feed, casein, etc.). Taking into account the fact that the implementation of such measures was originally planned from 01.07.2018, part of the owners who donated milk for processing, lost cows in advance, as confirmed by the data in table 2: in 2018, the number of cows in households decreased by $6.42 \%$ compared to 2017 .

An important factor affecting the desire of farms and households to keep cows is the purchase price of milk. The average price of milk sold by agricultural enterprises in January - October 2019 was $8058.7 \mathrm{UAH}$. per tonne, while milk sold by households - 6 497,2 UAH. per ton. Poor quality of milk produced by households leads to low purchase prices, which, together with the diminishing demand for such milk from processing companies, will result in the fact that the quantity of milk produced by households and its marketability will continue to decline. The increase in the purchase prices for extra grade milk, the highest and the first observed in the context of shortage of dairy raw materials, is a favorable factor for agricultural enterprises.

Along with the decline in the number of cows, milk production in the country is affected by farm productivity. In 2018, compared to 2013, the average annual milk yield per cow increased by $467 \mathrm{~kg}$ or $10.48 \%$ (Table 3 ). However, in agricultural enterprises in 2018, cow productivity averaged $6190 \mathrm{~kg}$ of milk per year, while in households $4559 \mathrm{~kg}$. The calculation of the chain index shows that the average annual milk yield per cow in agricultural enterprises increased by an average of $5 \%$ per year during the study period, while the increase in cow productivity in households was less than $1 \%$ per year. That is why the reduction in the number of cows in households while stabilizing average annual milk yields leads to a decrease in milk production in the country. While increasing cow productivity in farms, despite the decline in livestock, has made it possible to increase milk production in this category of farms.

The performance of the cows was influenced by the improvement of breeding and breeding work, the strengthening of the forage base and the improvement of the conditions of keeping the cows. In particular, high-performance herds of Ukrainian black-spotted dairy breed were created in breeding plants, which was created by crossing black-spotted cattle of domestic breeding with Holstein. However, it should be remembered that Ukraine is far behind the level of productivity of dairy cattle from the developed countries of the world.

Thus, in order to increase milk production, cows' livestock production should be stopped and their productivity improved. To this end, the State Budget of 2018 and 2019 provided funds for livestock support and approved the Cabinet of Ministers of Ukraine Decree "On Approval of the Procedure for Using the Funds Provided in the State Budget for Support of Livestock, Storage and Processing of Agricultural Products, Aquaculture (Fisheries) - 2018 № 107, according to which the budget funds were directed to the state support of animal husbandry in the following areas:

- partial compensation for the cost of construction and reconstruction of livestock farms and complexes, milking parlors, agricultural processing enterprises in terms of costs financed without value added tax due to bank loans (offsetting the value of the objects financed by banks);

- special budgetary subsidy for keeping cows of dairy, dairy and meat and productivity direction (subsidy for keeping cows);

- special budget subsidy for the rearing of young cattle (subsidy for young animals);

- partial reimbursement of the value of the breeding animals purchased for further reproduction, namely heifers, heifers, dairy cows, dairy and meat products, pigs and rams, ewes, rams, boar boars and cattle, and embryos, which 
have a breeding (genetic) value (partial reimbursement of the value of breeding animals, semen and embryos);

- partial reimbursement of the cost of construction and reconstruction of livestock farms and complexes, milking parlors, agricultural enterprises (partial reimbursement of livestock facilities) [6].

However, it is unknown whether these livestock support programs will continue to operate.

\section{CONCLUSION}

To stop the decrease in milk production is possible only with the comprehensive support of the dairy cattle industry by the state.

For this purpose it is necessary to create a working group, which should include, in particular, representatives of the Association of Milk Producers, the Union of Dairy Enterprises of Ukraine, the Association of Cattle Breeders of Ukraine, and to develop a program for the development of the dairy industry. It should be calculated for at least five years, which is related to the long payback period of dairy cattle. The predictability of agrarian policy towards the industry and the certainty that the state support rate is unchanged will create clear rules for the game for agricultural producers.

The dairy development program should, first of all, provide for preferential conditions (lending, compensation of interest rates on land loans) and priority right to purchase allotments for growing roughage of dairy farming enterprises.

We consider it expedient to retain such government support programs as offsetting the cost of bank-financed assets; partial reimbursement of the cost of livestock facilities; partial reimbursement of the cost of breeding animals, semen and embryos; subsidy for the young.

We agree with the proposal of the Association of Milk Producers regarding the need to replace special budgetary subsidies for keeping cows with subsidies for the volume of sales, which will encourage farmers to increase the productivity of the herd.

\section{$\Lambda$ ітература:}

1. Україна на 22 місці у рейтингу світових виробників молока. URL: http://avm-ua.org/uk/ post/ukraina-na-22-misci-u-rejtingu-svitovihvirobnikiv-moloka

2. Козак О.А., Грищенко О.Ю., Васильченко О. М. Прогноз виробництва молока в Україні до 2030 року: методика і розрахунки. Київ: ННЦ "IАЕ", 2019. 24 с.

3. За 6 місяців в Україні закрилось 100 молочних ферм - тваринники готуються до від- криття ринку землі. URL: https://www.epravda.com.ua/news/2019/10/17/652684/

4. Рекомендації щодо здорового харчування дорослих. URL: https://moz.gov.ua/uploads/ ckeditor $/ \% \mathrm{D} 0 \% \mathrm{~B} 4 \% \mathrm{D} 0 \% \mathrm{BE} \% \mathrm{D} 0 \% \mathrm{BA} \% \mathrm{D} 1 \%$ $83 \% \mathrm{D} 0 \% \mathrm{BC} \% \mathrm{D} 0 \% \mathrm{~B} 5 \% \mathrm{D} 0 \% \mathrm{BD} \% \mathrm{D} 1 \% 82 \% \mathrm{D} 0 \% \mathrm{~B} 8 /$ 01122017_Basic_Recommendations-1.pdf

5. АСТ Т 3662:2018 "Молоко-сировина коров`яче. Технічні умови". URL: http://online.budstandart.com/ua/catalog/doc-page.html?id $\mathrm{doc}=77350$

6. Про затвердження Порядку використання коштів, передбачених у державному бюджеті для підтримки тваринництва, зберігання та переробки сільськогосподарської продукції, аквакультури (рибництва): Постанова КМУ від 7 лютого 2018 р. № 107. URL: https://zakon.rada.gov.ua/laws/show/107-2018-\%D0\%BF

\section{References:}

1. The official site of Association of milk producers (2019), "Ukraine is ranked 22nd in the ranking of world milk producers", available at: http://avm-ua.org/uk/post/ukraina-na-22-misciu-rejtingu-svitovih-virobnikiv-moloka (Accessed 10 May 2020).

2. Kozak, O. A. Gryshchenko, O. Y. and Vasilchenko, O. M. (2019), Prohnoz vyrobnytstva moloka v Ukraini do 2030 roku: metodyka i rozrakhunky [Forecast of milk production in Ukraine until 2030: methodology and calculations], IAE Research Center, Kyiv, Ukraine.

3. Ekonomichna pravda (2019), "100 dairy farms closed in Ukraine in 6 months - livestock farmers are preparing to open the land market", available at: https://www.epravda.com.ua/news/ 2019/10/17/652684/ (Accessed 10 May 2020).

4. The official site of The Ministry of Health of Ukraine (2017), "Adult healthy eating guidelines", available at: https://moz.gov.ua/uploads/ckeditor $/ \% \mathrm{D} 0 \% \mathrm{~B} 4 \% \mathrm{D} 0 \% \mathrm{BE} \% \mathrm{D} 0 \% \mathrm{BA} \% \mathrm{D} 1 \% 83 \%$ D0\%BC\%D0\%B \% \% $\%$ BDD $\% 1 \% 82 \% \mathrm{D} 0 \% \mathrm{~B} 8 /$ 01122017 Basic_Recommendations-1.pdf (Accessed 10 May 2020).

5. DP "UkrNDNTs" (2018), "DSTU 3662:2018 "Raw cow's milk. Specifications", available at: http://online.budstandart.com/ua/catalog/docpage.html?id_doc $=77350$ (Accessed 10 May 2020).

6. Cabinet of Ministers of Ukraine (2018), Resolution "On approval of the Procedure of using the funds provided in the state budget for support of livestock, storage and processing of agricultural products, aquaculture (fisheries)", available at: https://zakon.rada.gov.ua/laws/show/107-2018$\%$ D0\%BF (Accessed 10 May 2020).

Стаття надійшла до редакцї 15.05.2020 p. 